Sains Malaysiana 49(3)(2020): 461-470

http://dx.doi.org/10.17576/jsm-2020-4903-01

\title{
Multivariate Analysis of Superior Helianthus annuus L. Genotypes Related to Metric Traits
}

(Analisis Multivariat Genotip Superior Helianthus annuus L. berkaitan Sifat Metriks)

\author{
Adeel Riaz*, Muhammad Shahid IQbal, Sajid Fiaz, Sadaruddin Chachar, \\ RAI MUHAMMAD AMIR \& BISMA RIAZ
}

\begin{abstract}
To increase seed yield and oil contents, variability in breeding material is a pre-requisite. Plant material was comprised of forty-nine sunflower genotypes to investigate the variability and identification of superior genotypes by multivariate analysis. The data were recorded for ten quantitative traits; days to maturity (DM), plant height (PH), stem diameter (SD), head diameter (HD), number of leaves (NOL), achene per head (APH), achene yield per plant (AYP), 100-achene weight (100AW), filled achene percentage (FA) and oil contents (OC). The genotypes showed significant variation for all traits except OC. A highly significant association of achene yield was observed with 100AW. Principal component analysis (PCA) separated into four components (PC-I, II, III, IV) with Eigenvalue greater than one accounting for $62.63 \%$ of the total variation. Total variance percentage was maximum in PC-I (24.4\%) followed by PC-II (14.70\%). Cluster analysis further classified the sunflower genotypes in three clusters based on seed yield and its related traits. A maximum number of genotypes were included in cluster I (26 genotypes) followed by cluster III (11 genotypes) contributing $65.30 \%, 24.48 \%$, respectively of total genotypic strength. In addition, maximum number of traits were included in cluster III followed by cluster II. PH and NOL were closest of all the ten traits suggesting their strong correlation. Taken together, these results can be useful for breeders to develop high yielding sunflower hybrids.
\end{abstract}

Keywords: Biplot; cluster analysis; multivariate; PCA; sunflower

\section{ABSTRAK}

Dalam usaha meningkatkan hasil benih dan kandungan minyak, kepelbagaian bahan pembiakan adalah pra-syarat. Bahan tumbuhan terdiri daripada 49 genotip bunga matahari untuk mengkaji kepelbagaian dan pengenalpastian genotip superior oleh analisis multivariat. Data direkodkan untuk sepuluh ciri kuantitatif; hari kepada kematangan $(D M)$, ketinggian tumbuhan (PH), diameter stem (SD), diameter kepala (HD), bilangan daun (NOL), aken setiap kepala (APH), hasil aken setiap tumbuhan (AYP), berat 100-aken (100AW), peratusan aken tetisi (FA) dan kandungan minyak (OC). Genotip menunjukkan variasi ketara bagi semua ciri kecuali OC. Satu pertalian yang sangat signifikan untuk hasil aken diperhatikan dengan 100AW. Analisis komponen utama (PCA) dipisahkan kepada empat komponen (PC-I, II, III, IV) dengan nilai eigen lebih besar daripada satu untuk mewakili 62.63\% daripada jumlah ubahan. Peratus jumlah varians adalah maksimum dalam PC-I (24.4\%) diikuti dengan PC-II (14.70\%). Analisis kelompok seterusnya mengelaskan genotip bunga matahari dalam tiga kelompok berdasarkan hasil benih dan ciri berkaitan. Bilangan maksimum genotip telah dimasukkan dalam kelompok I (26 genotip) diikuti oleh kelompok III (11 genotip), masingmasing menyumbang kepada $65.30 \%$ dan 24.48\% daripada jumlah kekuatan genotip. Tambahan pula, bilangan ciri maksimum dimasukkan dalam kelompok III diikuti oleh kelompok II. PH dan NOL adalah paling hampir daripada semua sepuluh ciri yang menunjukkan korelasi mereka yang kukuh. Dengan mengambil kira keputusan ini, penternak boleh membangunkan kacukan bunga matahari untuk hasil yang lebih tinggi.

Kata kunci: Analisis kluster; Biplot; bunga matahari; multivariat; PCA

\section{INTRODUCTION}

Edible oil is a significant component of daily diet. Sunflower as most important oilseed crop have potential to minimize the huge gap between production of edible oil and consumption. Maximum variability is a pre-requisite for sunflower yield improvement (Riaz et al. 2017). The introduction of new cultivars or hybrids could help to achieve higher oil yield. Hybrids and their parental lines representing higher yield can replace open pollinated varieties of sunflower (Ghaffari et al. 2011). Because hybrids are more vigorous, uniform and self-fertile ultimately led to boost in productivity (Barman et al. 2019). Therefore, enhancement of genetic potential of sunflower is a possible solution to increase oil yield (Hu et al. 2010).

Helianthus annuus L. predicts sizeable genetic variability in subsequent generations. Genetic variability indicates the difference between individuals of same species (Riaz et al. 2019b). The knowledge about genetic 
association and diversity in the breeding material may help in crop improvement strategies (Nisar et al. 2008; Riaz et al. 2019a). Many researchers have employed different strategies to check genetic diversity in sunflower for investigating important agronomic traits (Ghafoor \& Arshad 2008; Muhammad et al. 2009).

Economically important seed yield and contributing traits often misled by making correlation coefficients larger and unreliable during selection (Dewey \& Lu 1959). Multivariate analysis is an efficient tool to quantify the degree of divergence among genotypes that provides information on relative contributions of desired traits to total divergence and understanding the genetic basis of essential plant traits (Sultana \& Ghafoor 2009). The principal components analysis (PCA) transforms correlated variables further into a smaller number of variables, i.e., principal components (PCs). The PCs are orthogonal and represents linear transformations of the original variables as well as independently of each other which correspond to a precise meaning (Jobson 1991). Each component shows different properties of experimental data and interprets separately. It could be developed to initiate two or three scatter plot of individuals or genotypes. The geometrical distances among genotypes are directly proportional to the genetic distances (Mohammadi \& Prasanna 2003).

The selection of hybrids or genotypes for high yield or early maturity in sunflower can be achieved by aligning genotypes with important agronomic traits (Ghaffari et al. 2011; Riaz et al. 2019a; Tabrizi et al. 2009). In addition, PCA analysis has been found to be a useful tool for selecting best genotypes in sunflower (Arshad et al. 2010; Wattoo et al. 2018). However, the limitation is that it does not provide adequate traits representation for relative importance when some traits are under considerations (Nwangburuka et al. 2011). Single linkage cluster analysis (SLCA) highlights the pattern of association between genotypes (Ariyo \& Odulaja 1991). Cluster analysis (CA) uses dendrograms to exhibit how several genotypes were differentiated and classify the individuals of same characteristics in a group, pursuing minimum variance within groups and maximum between the groups (Souza \& Sorrells 1991). This method is advantageous in predicting the traits contributing directly to yield and later these traits must be emphasized in the further breeding program. Keeping in view the importance of multivariate approach, this study was conducted to illustrate the genetic variation in breeding material, correlation among traits and identify the best genotypes by PCA, biplot display and CA.

\section{MATERIALS AND METHODS}

\section{EXPERIMENTAL CONDITIONS}

The current study was conducted at the experimental area of the Faculty of Agriculture, University of Agriculture
Faisalabad, Pakistan to evaluate forty-nine sunflower genotypes for ten metric traits including DM, PH, SD, HD, NOL, APH, AYP, 100AW, FA and OC. The city Faisalabad is situated at the rolling flat plains of North East Punjab between longitudes $73^{\circ}-60^{\circ}$ East, latitude $30^{\circ}-26^{\circ}$ North, with an elevation of $184 \mathrm{~m}$ above sea level. Monthly average minimum and maximum temperature and monthly total rainfall of 2015-2016 during crop period are shown in supplementary Figure 1(a) and Figure 1(b), respectively.

\section{EXPERIMENTAL MATERIAL AND LAYOUT}

All sunflower genotypes were planted in a randomized complete block design (RCBD) with three replications. Each genotype was grown in three rows of $5 \mathrm{~m}$ length having $75 \mathrm{~cm}$ spacing between the rows and $25 \mathrm{~cm}$ within rows. Sowing was done manually on ridges with the help of dibbler placing 4-5 seeds per hole to a depth of $2-3 \mathrm{~cm}$ to maintain optimum plant population. All the recommended cultural and agronomic practices (Lira et al. 2017) were uniformly performed for all experimental units from the time of sowing to the time of harvesting.

\section{DATA RECORDING}

At maturity, ten guarded plants per row of representing a genotype were selected randomly as an experimental unit from each replication. DM of each selected plant was measured as the number of days from planting to the day when the plants showed maturity. PH of the main stem was measured in centimeters $(\mathrm{cm})$ from ground level to the base of the head. SD and HD were taken with the help of measuring tape in centimeters. NOL originated from the main stem of each plant were counted. AYP were counted after threshing each head separately. After threshing the weight of achene from each head and $100 \mathrm{AW}$ was recorded in grams by using an electronic balance (Setra BL-410S). From the harvested achene of each plant, the filled and unfilled achene were counted separately, and FA percentage was calculated by the formula:

$$
\text { Filled achene percentage }=\frac{\text { Number of achene per head }}{\text { Total number of achene per head }} \times 100
$$

\section{STATISTICAL ANALYSIS}

Average values of each trait were subjected to Analysis of variance (ANOVA), simple correlation and multivariate analysis including PCA, biplot display, and CA. PCA was performed to check and explain the pattern of morphological variation. Simple correlation coefficients between the traits and PCs were calculated. Cluster analysis (CA) divides the genotypes into similar groups based on their agronomic traits. Clustering of genotypes into similar groups was analyzed using a hierarchical algorithm based on squared Euclidean distances. Multivariate analysis was performed 
using Rstudio version 1.1.643 (Team 2015). The dendrogram was built with the use of package dendextend.

\section{RESULTS AND DISCUSSION}

\section{CORRELATION MATRIX (PEARSON) FOR METRIC TRAITS}

The sunflower genotypes were subjected to determine the association among yield related traits and extent of diversity in the gene pool. The correlation matrix between metric traits was found to be significant and positive for some traits (Table 1). Simple correlation studies provide insight for the selection of quantitative traits important for ideal plant types. In addition, indirect selection of yield contributing traits is considered to be more important than direct selection due to chances of misrepresentations (Awan et al. 2015). A highly significant association of AYP was observed with 100AW. PH depicted highly significant positive correlation with NOL while AYP with 100AW (Supplementary Figure S2); these traits may be indirectly selected through PH. Significant positive correlations of achene yield with essential traits indicated the prominence of its role in casting these traits. The significant positive correlation was perceived between $\mathrm{PH}$ and AYP while profoundly negative between AYP and OC. Highest significant positive associations of 100AW and AYP, as well as the profoundly negative association of $\mathrm{OC}$ and achene yield was reported by Rehman et al. (2012). Mohammadi et al. (2011) also reported a significant relationship between achene yield and 100AW. However, negative association between achene yield and achene weight was found by Gaffari et al. (2011). The results indicated the importance of physiological traits such as 100AW, APH, PH and their positive impact on achene yield. Therefore, other statistical techniques such as multivariate approach should be used to confirm these results or to detect a probable association with grain yield per plant.

\section{PRINCIPLE COMPONENT ANALYSIS}

The collected experimental data was examined by PCA to visualize the response patterns of agronomic traits in different PCs. Four PCs (PC-I, II, III, IV) explained the
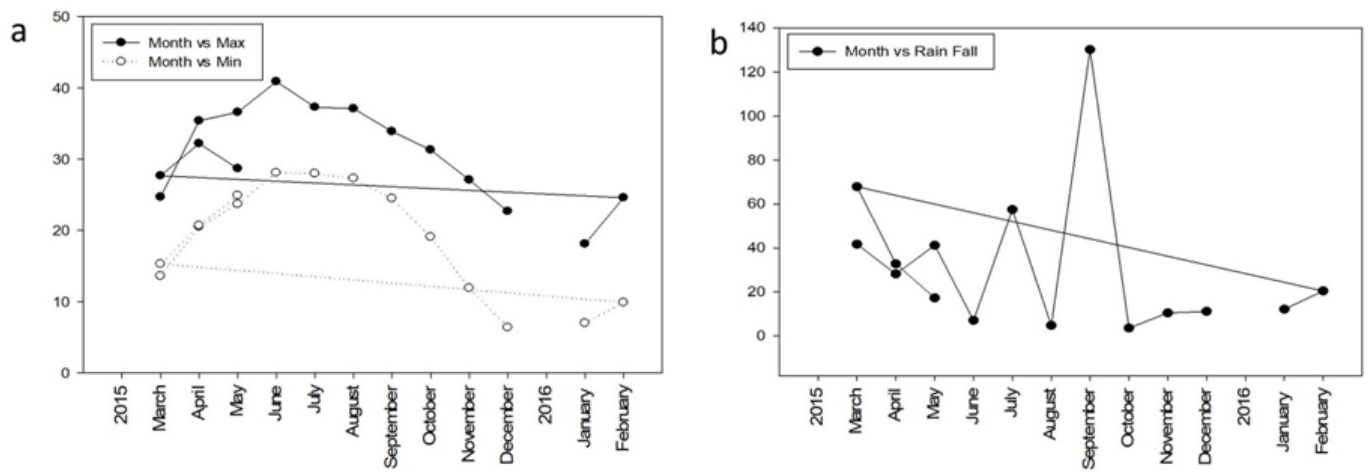

FIGURE S1. Average monthly minimum and maximum temperature $\left({ }^{\circ} \mathrm{C}\right)(\mathrm{a})$ and total rainfall $(\mathrm{mm})(\mathrm{b})$ prevailing during crop period

TABLE 1. Pearson correlation coefficients between measured traits of sunflower genotypes

\begin{tabular}{|c|c|c|c|c|c|c|c|c|c|c|}
\hline Traits & $\mathrm{DM}$ & $\mathrm{PH}$ & SD & HD & NOL & $\mathrm{APH}$ & AYP & $100 \mathrm{AW}$ & FA & $\mathrm{OC}$ \\
\hline $\mathrm{DM}$ & 1 & & & & & & & & & \\
\hline $\mathrm{PH}$ & -0.059 & 1 & & & & & & & & \\
\hline SD & -0.151 & 0.106 & 1 & & & & & & & \\
\hline HD & -0.075 & 0.155 & $0.256^{*}$ & 1 & & & & & & \\
\hline NOL & -0.183 & $0.550 * *$ & $0.223^{*}$ & 0.154 & 1 & & & & & \\
\hline $\mathrm{APH}$ & $-0.156^{*}$ & $0.240^{*}$ & 0.159 & 0.075 & $0.260^{*}$ & 1 & & & & \\
\hline AYP & -0.070 & $0.348^{*}$ & 0.017 & 0.148 & 0.165 & $0.293^{*}$ & 1 & & & \\
\hline 100AW & -0.097 & 0.114 & 0.151 & $0.263^{*}$ & 0.180 & 0.139 & $0.503 * *$ & 1 & & \\
\hline FA & $-0.261^{*}$ & 0.064 & 0.174 & 0.027 & $0.263^{*}$ & -0.022 & -0.038 & 0.067 & 1 & \\
\hline $\mathrm{OC}$ & 0.100 & 0.077 & -0.053 & 0.077 & $0.265^{*}$ & 0.190 & $-0.159 *$ & $-0.140 *$ & 0.071 & 1 \\
\hline
\end{tabular}

** Significant at $\mathrm{P} \leq 0.01$ level and * Significant at $\mathrm{P} \leq 0.05$ level

$\mathrm{DM}=$ days to maturity, $\mathrm{PH}=$ plant height, $\mathrm{SD}=$ stem diameter, $\mathrm{HD}=$ head diameter, $\mathrm{NOL}=$ number of leaves, $\mathrm{APH}=$ achene per head, $\mathrm{AYP}=$ achene $\mathrm{yield}$ per $\mathrm{plant}$, $100 \mathrm{AW}=100$ achene weight, $\mathrm{OC}=$ oil contents 
TABLE 2. Eigen values and percent variation accounted by the first four principal components

\begin{tabular}{lcccc}
\hline Components & PC-I & PC-II & PC-III & PC-IV \\
\hline Eigen value & 2.44 & 1.47 & 1.29 & 1.04 \\
Variability (\%) & 24.44 & 14.70 & 12.99 & 10.49 \\
Cumulative (\%) & 24.44 & 39.14 & 52.14 & 62.63 \\
\hline
\end{tabular}

cumulative $62.63 \%$ of the data variance (Table 2). They were chosen on the basis on the Eigenvalues greater than one that usually considered as the criterion of significance. While, the traits having less than 0.2 Eigenvalue are supposed to have no effect to overall variation (Adebisi et al. 2013). Ramya et al. (2017) also identified four principal components for determination of genetic diversity by PCA. In addition, PCA was used to determine the linear combinations which represent most of the variation in the dataset (Kholghi et al. 2011; Tabrizi et al. 2011).

First principal component (PC-I) explained $24.4 \%$ of the total variation (Scree plot; Figure 1). The second principal component (PC-II) was responsible for $14.70 \%$ of total variation of quantitative traits. Ruzdik et al. (2015) also reported same results for evaluation of sunflower hybrids by multivariate analysis. While PC-III (12.99\%) and PC-IV (10.49\%) of the total variation. The traits contributed more positively to PC-I were NOL (0.50), PH (0.42), AYP (0.34) and 100AW (0.29) while the rest of traits showed low eigenvector values (Table 3 ). This indicated that the populations with greater $\mathrm{PC}-1$ values are high yielding and formed by having more NOL, PH, AYP and 100AW. Maximum genetic variance to PC-II was contributed by OC (0.43), AYP (0.33) and 100AW (0.33). The second component was strongly associated with OC, AYP and 100AW. The PC-III showed that DM (0.31) and FA (0.30) contributed more positively. However, $\mathrm{PH}$ and SD also contributed positively but low values. In fourth component PC-IV, HD (0.49) showed strong association while rest of traits in this component has a positive association with low to moderate value. It is evident that quantitative traits contributed positively to four PCs and gave sufficient ground to assess variability in genetic materials.

\section{BIPLOT DISPLAY}

Four principal components (PCI-IV) were taken to check the graphical display of biplot analysis (Figure 2). The genotypes divided into four sectors. All the measured parameters including DM, PH, SD, HD, NOL, APH, AYP, $100 \mathrm{AW}, \mathrm{FA}$, and OC were distributed in the biplot according to their loading and mean values. The traits NOL, PH, and AYP were contributing positively in PC-I while OC and AYP for PC-II. Biplot has different considerations, as it comprised of a distinct group of genotypes by distributing around the vectors and angles of vectors. In the vector view of biplot, a vector is drawn from the origin of biplot to each symbol of the traits to make easy visualization of association between the traits (Yan \& Rajcan 2002). The biplot analysis explains a suitable amount of the total variation, the correlation coefficient between any of two characters can be approximated by the cosine of the angle between the vectors (Yan \& Kang 2003). The positive correlation is indicated if the angle of vectors between two traits less than 90, negatively correlated if more than 90 . However, they are independent if the angle is an exact 90 (Yan \& Rajcan 2002).

This distribution provides multi-traits selection with association for sunflower breeding (Ghaffari et al. 2011). Figure 2 shows that G23, G24, and G38 genotypes scattered around the AYP vector. It can be explained by the attention to the mean values of these genotypes for AYP while angles of vectors showed the correlation among traits (smaller the angle, more significant correlation). Yan and Kang (2003) gave a clue about what the angle of vectors shows correlations of vectors among traits. The biplot diagram had some vectors with small angles indicating their positive correlation. However, DM was found to be negatively correlated with all other traits due to opposite angle direction. The contributions of sunflower traits percentage (Supplementary Figure S2), their Eigenvalue against the traits showed that the line is becoming gradually straighter indicated each succeeding trait or factor is amounting for lesser and lesser magnitude of variability.

The components which contributed to the total variance were plotted graphically to observe the correlation between traits (Figure 3). The geographical heat plot was also developed to show the relationship of ten sunflower traits (Supplementary Figure S4). PCA functions to reduce multivariate data into a few potential genotypes and further classification of material. This approach is especially valuable for the screening large number of genetic resources by a large number of descriptor variables (Beiragi \& Khorasani 2011; Golbashy et al. 2010).

Based on the present results it was recommended that crosses could be made between the genotypes grouped in three clusters based on metric traits (Figure 4). The cluster III included maximum numbers of traits including 100AW, AYP, APH, PH, NOL, DM and OC (Figure 4). PH and NOL were closest of all ten traits suggesting their strong correlation. 100AW and NOL were outliers in this cluster. The cluster II exhibited relationship among FA, SD, and HD. While DM and OC were included in cluster I. Grouping of genotypes with agronomic traits and sophisticated multivariate techniques can reduce the time 


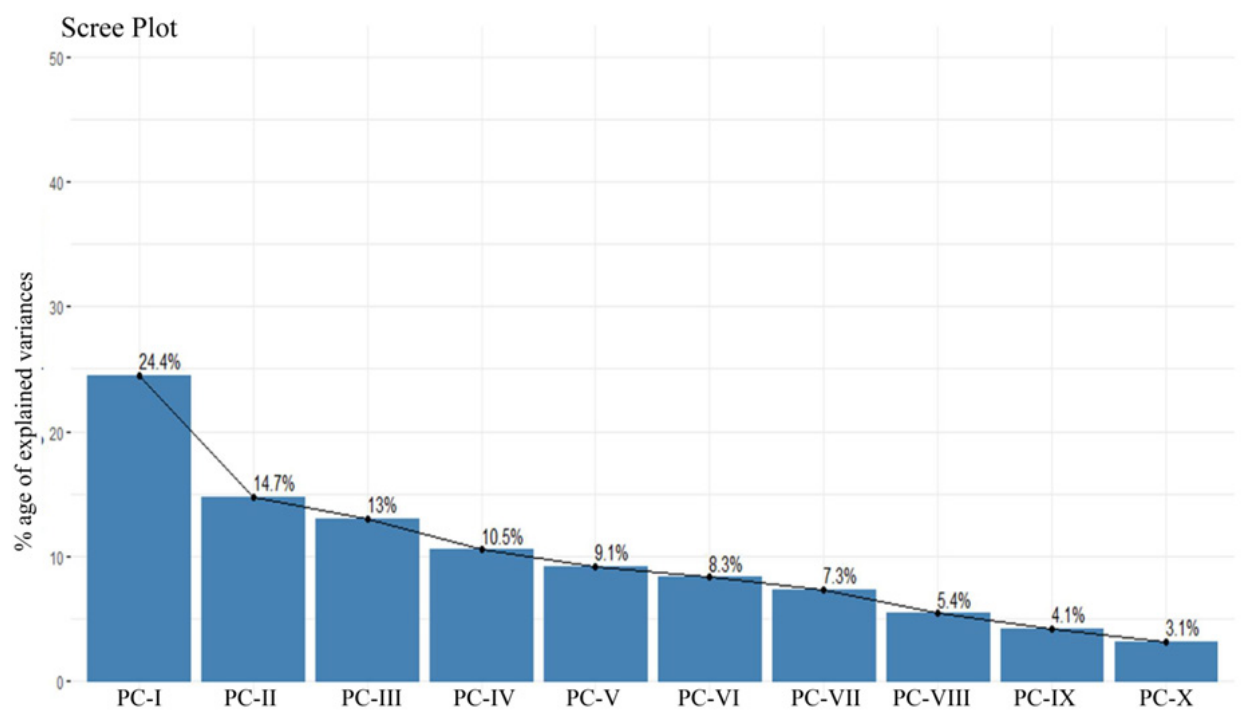

FIGURE 1. Scree Plot for the selection of components representing maximum variability to be plotted on biplot as described by ten variables studied for sunflower genotypes

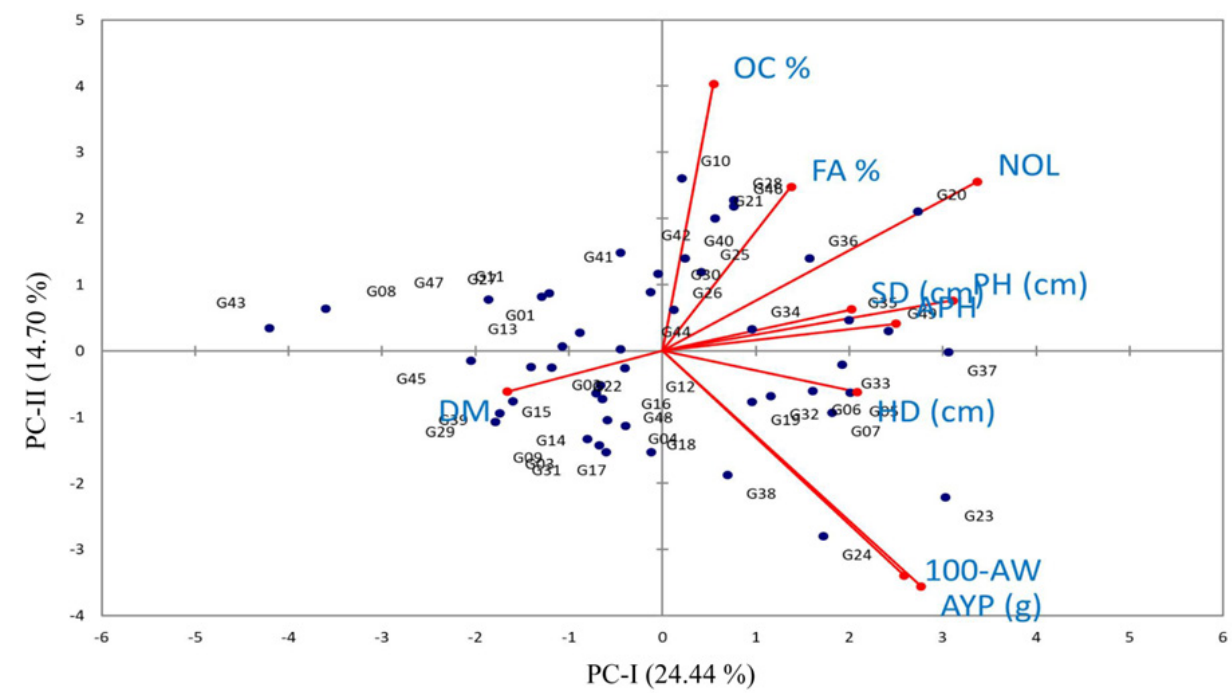

FIGURE 2. Biplot plot display of PC-I and PC-11 for sunflower genotypes in association with metric traits. The traits are spelled out in uppercase letters, and each genotype represented by numbers

TABLE 3. Eigen vectors load depicting impact of sunflower traits on four main components

\begin{tabular}{lllll}
\hline DM & 0.123 & 0.010 & 0.311 & 0.147 \\
\hline PH & 0.428 & 0.015 & 0.121 & 0.031 \\
SD & 0.181 & 0.010 & 0.198 & 0.184 \\
HD & 0.192 & 0.010 & 0.014 & 0.499 \\
NOL & 0.505 & 0.175 & 0.014 & 0.010 \\
APH & 0.277 & 0.004 & 0.094 & 0.012 \\
AYP & 0.340 & 0.338 & 0.052 & 0.043 \\
100AW & 0.297 & 0.307 & 0.010 & 0.008 \\
FA & 0.084 & 0.164 & 0.306 & 0.051 \\
OC & 0.013 & 0.434 & 0.176 & 0.059 \\
\hline
\end{tabular}

$\mathrm{DM}=$ days to maturity, $\mathrm{PH}=$ plant height, $\mathrm{SD}=$ stem diameter, $\mathrm{HD}=$ head diameter, $\mathrm{NOL}=$ number of leaves, $\mathrm{APH}=$ achene per head, $\mathrm{AYP}=$ achene $y i e l d$ per plant, $100 \mathrm{AW}=100$ achene weight, $\mathrm{FA}=$ filled achene $\mathrm{OC}=$ oil contents, $\mathrm{PC}=$ principle component 


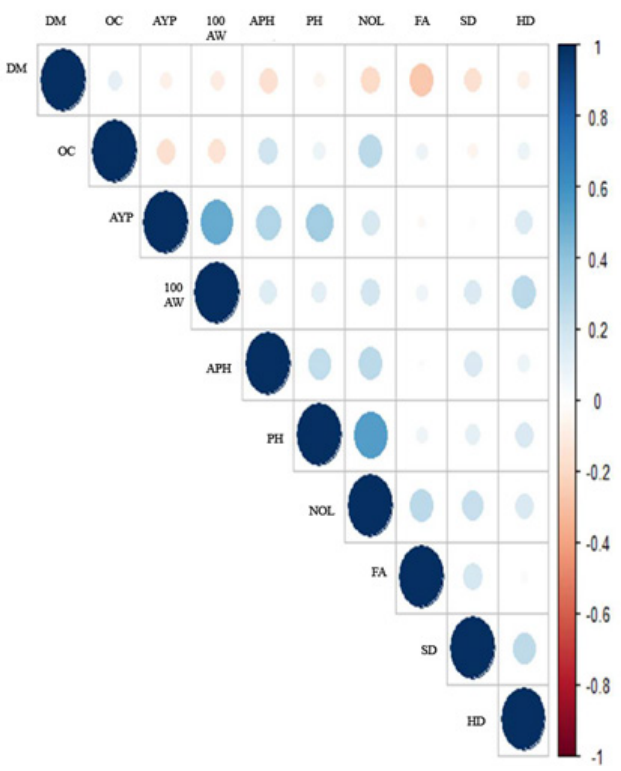

FIGURE S2. The correlations matrix among sunflower genotypes

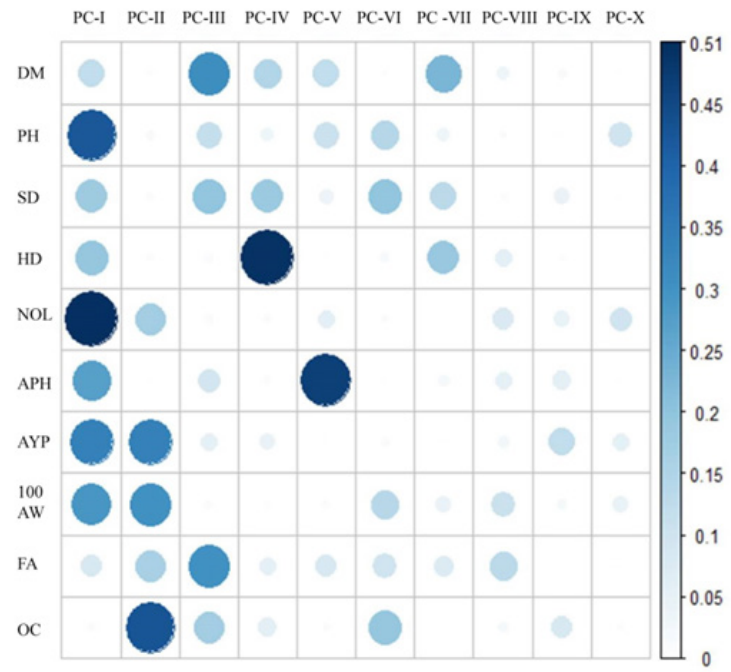

FIGURE 3. Correlation matrix among traits and PCs. The darker and large size dots represent significant correlations

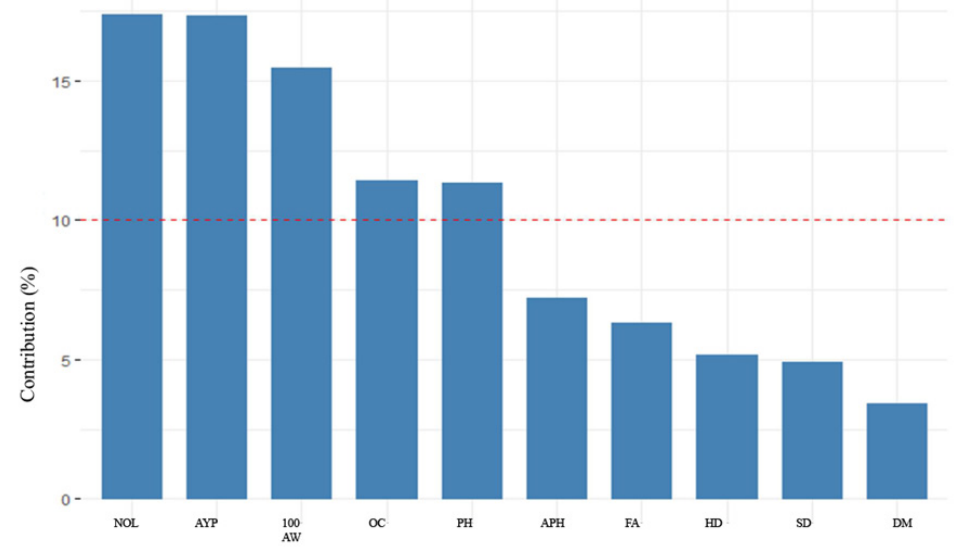

FIGURE S3. Contribution of sunflower traits for achene yield in sunflower 


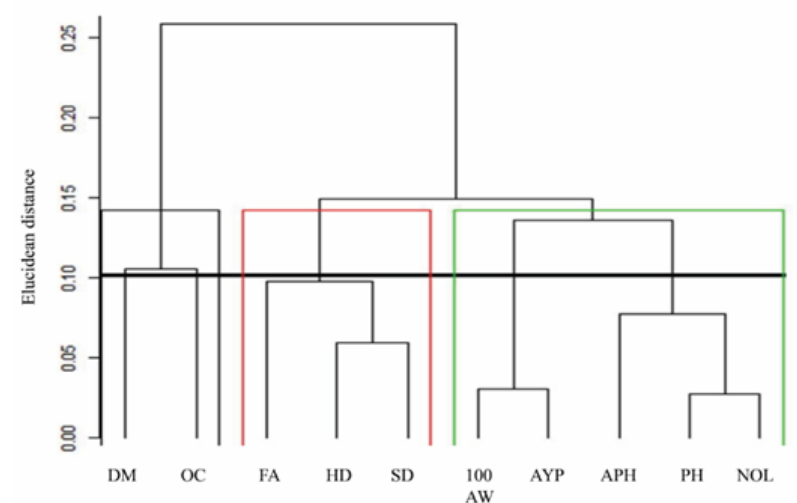

FIGURE 4. Cluster analysis of 10 metric traits (scale: Euclidean distance)

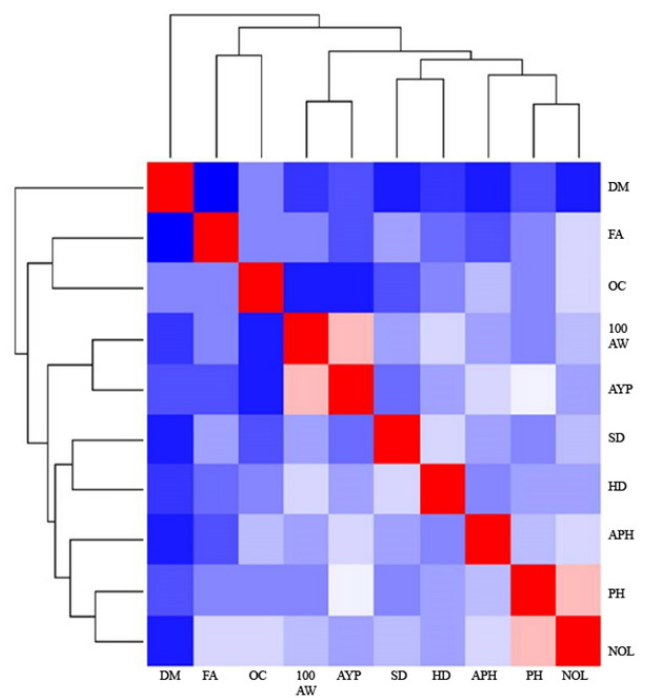

FIGURE S4. Heat plot showing the morphological relationship traits of sunflower

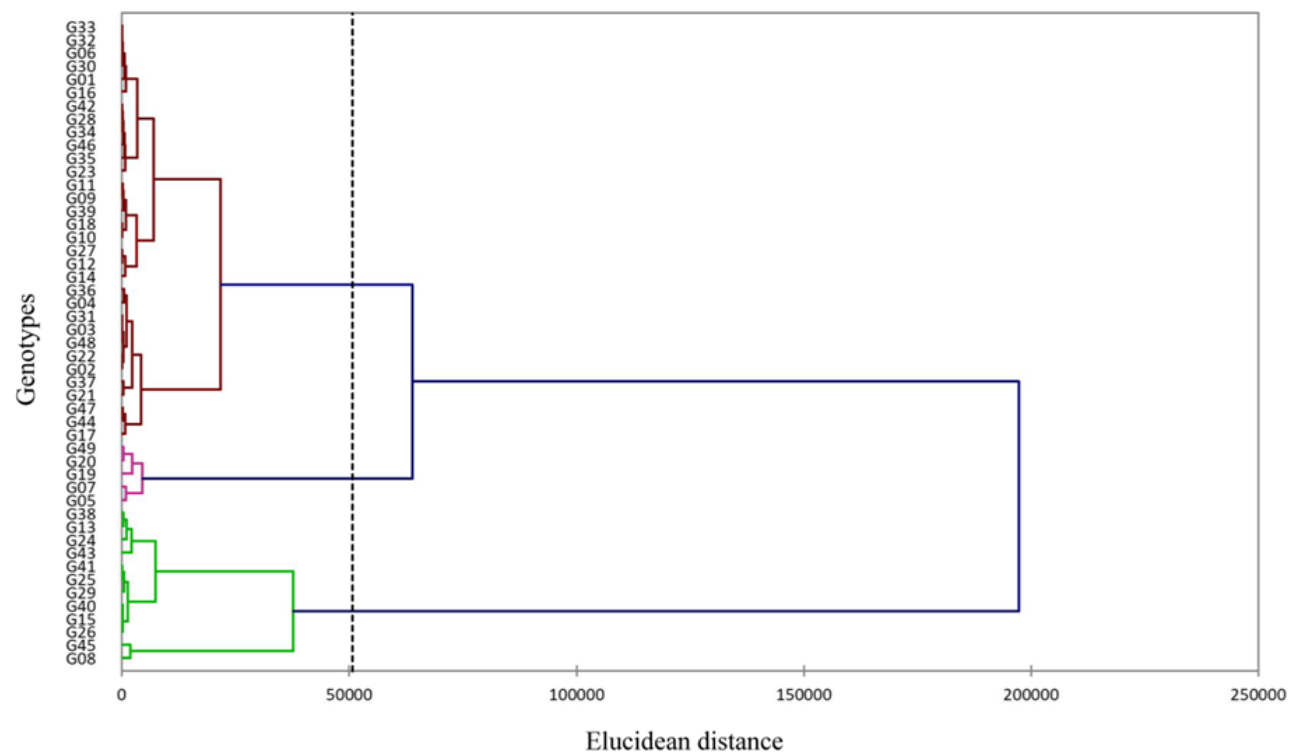

FIGURE 5. Dendrogram of the Cluster analysis showing grouping of 49 sunflower genotypes produced by Ward's cluster analysis (scale: Elucidean distance) 


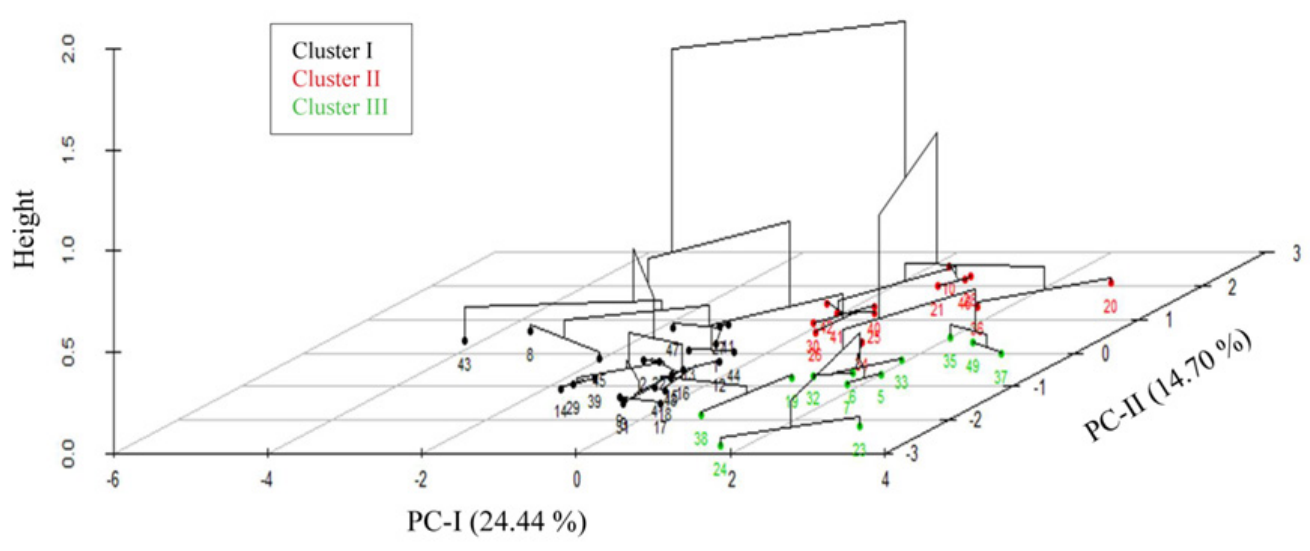

FIGURE 6. Hierarchical clustering of 49 sunflower genotypes

and money in crop improvement. However, stability analysis of different traits on the already established groups of the current study requires further investigation under years and locations.

The dendrogram drawn from the single linkage cluster analysis (SLCA) showed the relationship between 49 genotypes (Figure 5). All the allocated genotypes were distinct from each other at $100 \%$ level of similarity. Earlier, Sangita and Ramesh (2010) and Singh et al. (2017) also indicated the significance of diversity through dendrogram. The distribution pattern of all the genotypes into three clusters showed the presence of considerable genetic diversity among the genotypes for most of the traits. The results showed that genotype 33 (G33) has more genetic distance to $\mathrm{G} 08$; therefore, the cross of $\mathrm{G} 08 \times \mathrm{G} 33$ could be helpful to obtain maximum genetic divergence. The results of the genetic distance showed that there is room for the genetic improvement of sunflower genotypes and the generated information may use to plan-wide hybridization to exploit genetic diversity and maximize the expression of heterosis.

\section{CLUSTER ANALYSIS}

The investigated sunflower genotypes were classified into three groups by PCA following CA by genetic diversity of metric traits. Maximum and minimum cluster difference was found between clusters I \& II, III, \& I, respectively (Figure 6) indicating that any cross between genotypes belonging to the diverse group I and II will produce better hybrids and recombinants (Hussain et al. 2006). Higher inter-cluster distance produces diverse genotypes with better phenotypic performance and a different magnitude of gene expression. In such cases, there are chances to get the more favorable transgressive segregates. Therefore, inter and intracluster distance of cluster I \& II may be considered as more diverse.

In SLCA, the genotypes in three groups identify the share of genotypes and different traits. The hierarchical clustering on factor map based on Euclidean dissimilarity showed three clusters at linkage distance. The maximum number of sunflower genotypes (26) were recommended in cluster I followed by cluster III (12) and cluster II (11) contributing $65.30 \%, 10.20 \%$ and $24.48 \%$ of total genotypic strength, respectively (Supplementary Table S1). Similarly, thirteen morphological traits were divided into four clusters using hierarchical clustering in sunflower (Nooryazdan et al. 2010).

Moreover, cluster analysis of sunflower genotypes indicated that genotypes in each cluster had some specific traits. This grouping is applicable value to sunflower breeders. The grouping of the genotypes into separate, distinct clusters could lead to increase in heterotic effect of crossed progenies for high hybrid vigor and improved segregates. It was also inferred that sunflower genotypes indicated substantial genetic diversity for the majority of the traits. Taken together, the results showed that overall seed yield could be improved by selection and integration of traits such as NOL, PH, APH, 100AW and OC (Table 3). In addition, performance of genotypes for important traits with higher contribution in genetic divergence should

TABLE S1. Grouping of 49 genotypes in 3 clusters

\begin{tabular}{ll}
\hline Clusters & Genotypes \\
\hline Cluster I & G502, G503, G504, G508, G509, G511, G512, G513, G514, G515, G516, G517, G518, G522, G527, G528, G529, \\
& G531, G534, G539, G543, G544, G545, G547, G548 \\
Cluster II & G520, G521, G525, G526, G530, G536, G540, G541, G542, G546 \\
Cluster III & G506, G507, G519, G523, G524, G532, G533, G535, G537, G538, G549 \\
\hline
\end{tabular}


also be considered. Because the introgression of useful genes is important for maintenance of gene pool. The hybridization between the genotypes of maximum clusters distance produces most desirable and promising traits.

\section{CONCLUSION}

The present study used multivariate approach to appraise the measure of genetic variation in yield and related components among forty-nine sunflower genotypes. The first step in achieving an understanding of the germplasm divergence is an efficient utilization of genetic resources of sunflower. The multivariate analysis of PCA, biplot display, CA, and SLCA proved to be better tools for assessing genetic diversity and precise associations among genotypes. The selection of genotypes from different clusters and components having more than one positive trait may lead to improvement in achene yield and oil contents in sunflower.

\section{REFERENCES}

Adebisi, M.A., Okelola, F.S., Ajala, M.O., Kehinde, T.O., Daniel, I.O. \& Ajani, O.O. 2013. Evaluation of variations in seed vigour characters of West African rice (Oryza sativa L.) genotypes using multivariate technique. American Journal of Plant Sciences 04(2): 356-363.

Awan, S., Ahmad, S., Ali, M., Ahmed, M. \& Rao, A. 2015. Use of multivariate analysis in determining characteristics for grain yield selection in wheat. Sarhad Journal of Agriculture 31: 139-150.

Ariyo, Q. \& Odulaja, A. 1991. Numerical analysis of variation among accessions of Okra Abelmoschus esculentus (L.) Moench, Malvaceae. Annals of Botany 67(6): 527-531.

Arshad, M., Khan, M.A., Jadoon, S. \& Mohmand, A.S. 2010. Factor analysis in sunflower (Helianthus annuus L.) to investigate desirable hybrids. Pakistan Journal of Botany 42(6): 4393-4402.

Barman, H.N., Sheng, Z., Fiaz, S., Zhong, M., Wu, Y., Cai, Y., Wang, W., Jiao, G., Tang, S., Wei, X. \& Peisong, H. 2019. Generation of a new thermo-sensitive genic male sterile rice line by targeted mutagenesis of TMS5 gene through CRISPR/Cas9 system. BMC Plant Biology 19: 109.

Beiragi, M.A. \& Khorasani, S.K. 2011. A study on effects of planting dates on growth and yield of 18 corn hybrids (Zea mays L.). American Journal of Experimental Agriculture 1(3): 110-120.

Dewey, D.R. \& Lu, K. 1959. A correlation and path-coefficient analysis of components of crested wheatgrass seed production 1. Agronomy Journal 51(9): 515-518.

Ghaffari, M., Farrokhi, I. \& Mirzapour, M. 2011. Combining ability and gene action for agronomic traits and oil content in sunflower (Helianthus annuus L.) using F1 hybrids. Crop Breeding Journal 1(1): 73-84.

Ghafoor, A. \& Arshad, M. 2008. Multivariate analyses for quantitative traits to determine genetic diversity of blackgram Vigna mungo (L.) Hepper germplasm. Pakistan Journal of Botany 40(6): 2307-2313.

Golbashy, M., Ebrahimi, M., Khorasani, S.K. \& Choukan, R. 2010. Evaluation of drought tolerance of some corn (Zea mays L.) hybrids in Iran. African Journal of Agricultural Research 5(19): 2714-2719.
Hu, J., Seiler, G. \& Kole, C. 2010. Genetics, Genomics and Breeding of Sunflower. Boca Raton: Science Publishers.

Hussain, K., Singh, D., Ahmed, N. \& Nazir, G. 2006. Multivariate analysis in carrot (Daucus carota L.). Environment and Ecology 24(1): 37-41.

Jobson, J. 1991. Confidence regions for the mean-variance efficient set: An alternative approach toestimation risk Review of Quantitative Finance and Accounting 1(3): 235.

Kholghi, M., Bernousi, I., Darvishzadeh, R., Pirzad, A. \& Maleki, H.H. 2011. Collection, evaluation and classification of Iranian confectionary sunflower (Helianthus annuus L.) populations using multivaraite statistical techniques. African Journal of Biotechnology 10(28): 5444-5451.

Lira, E.G., Amabile, R.F., Fagioli, M. \& Montalvão, A.P.L. 2017. Genetic parameters, phenotypic, genotypic and environmental correlations and genetic variability on sunflower in the Brazilian Savannah. Ciência Rural, Santa Maria 47(08): e20160719.

Mohammadi, M., Karimizadeh, R., Shefazadeh, M.K. \& Sadeghzadeh, B. 2011. Statistical analysis of durum wheat yield under semi-warm dryland condition. Australian Journal of Crop Science 5(10): 1292-1297.

Muhammad, S., Bacha, S., Arshad, M., Din, R. \& Ghafoor, A. 2009. Genetic diversity for determining yield potential and selection criteria in Pisum sativum (L.) genetic resources. Pakistan Journal of Botany 41(6): 2987-2993.

Mohammadi, S. \& Prasanna, B. 2003. Analysis of genetic diversity in crop plants-salient statistical tools and considerations. Crop Science 43(4): 1235-1248.

Nisar, M., Ghafoor, A., Ahmad, H., Khan, M., Qureshi, A., Ali, H. \& Islam, M. 2008. Evaluation of genetic diversity of pea germplasm through phenotypic trait analysis. Pakistan Journal of Botany 40(5): 2081-2086.

Nooryazdan, H., Serieys, H., Baciliéri, R., David, J. \& Bervillé, A. 2010. Structure of wild annual sunflower (Helianthus annuus L.) accessions based on agro-morphological traits. Genetic Resources and Crop Evolution 57(1): 27-39.

Nwangburuka, C., Kehinde, O., Ojo, D., Denton, O. \& Popoola, A. 2011. Morphological classification of genetic diversity in cultivated okra, Abelmoschus esculentus (L) Moench using principal component analysis (PCA) and single linkage cluster analysis (SLCA). African Journal of Biotechnology 10(54): 11165-11172.

RStudio Team 2015. RStudio: Integrated Development for R. RStudio, Inc., Boston, MA URL http://www.rstudio.com/.

Ruzdik, N.M., Karov, I., Mitrev, S., Gjorgjieva, B., Kovacevik, B. \& Kostadinovska, E. 2015. Evaluation of sunflower (Helianthus annuus L.) hybrids using multivariate statistical analysis. Helia 38(63): 175-187.

Ramya, A.R., Ahamed, M.L. \& Srivastava, R.K. 2017. Genetic diversity analysis among inbred lines of pearl millet Pennisetum glaucum (L.) R. Br. based on grain yield and yield component characters. International Journal of Current Microbiology and Applied Sciences 6(6): 22402250.

Rehman, R., Arshad, M., Khan, M.A., Mohmand, A.S., Shabbir, G. \& Shah, M.K.N. 2012. Using multivariate analysis for selecting desirable hybrids in sunflower (Helianthus annuus L.). Pakistan Journal of Botany 44(5): 1715-1720.

Riaz, A., Tahir, M.H.N., Rizwan, M., Fiaz, S., Chachar, S., Razzaq, K., Riaz, B. \& Sadia, H. 2019a. Developing a selection criterion using correlation and path coefficient analysis in sunflower (Helianthus annuus L.). Helia 42(70): 85-99. 
Riaz, B., Saeed, A., Fiaz, S. \& Adeel, R. 2019b. Genetic diversity among Bt Cotton (Gossypium hirsutum L.) germplasm assessed through morphological and withinboll yield attributes. Journal of Animal and Plant Sciences 29(1): 226-231.

Riaz, A., Tahir, M.H.N., Rizwan, M., Nazir, F.M. \& Riaz, B. 2017. Combining ability analysis for achene yield and related components in sunflower (Helianthus annuus L.). Helia 40(67): 177-188.

Sangita, K. \& Ramesh, K. 2010. Genetic divergence studied in newly introduced genotype of lettuce (Lectuca sativa L.). African Journal of Basic and Applied Sciences 2: 18-24.

Singh, S., Ahmed, N., Singh, D., Srivastva, K. \& Mir, R.S.A 2017. Genetic variability determination in garden pea (Pisum sativum L. sub sp. hortense Asch. and Graebn.) by using the multivariate analysis. Legume Research-An International Journal 40(3): 416-422.

Souza, E. \& Sorrells, M. 1991. Relationships among 70 North American oat germplasms: I. Cluster analysis using quantitative characters. Crop Science 31(3): 599-605.

Sultana, T. \& Ghafoor, A. 2009. Botanical and molecular evidences of landraces from the germplasm exclusively collected from Baluchistan, a centre of diversity for lens culinaris. African Journal of Biotechnology 8(20): 53105315.

Tabrizi, Z., Şahin, E. \& Haliloğlu, K. 2011. Principal components analysis of some $\mathrm{F} 1$ sunflower hybrids at germination and early seedling growth stage. Journal of the Faculty of Agriculture of Atatürk University (Turkey) 42(2): 103-109.

Wattoo, F.M., Rana, R.M., Fiaz, S., Zafar, S.A., Noor, M.A \& Mumtaz, H. 2018. Identification of drought tolerant maize genotypes and seedling based morpho-physiological selection indices for crop improvement. Sains Malaysiana 47(2): 295-302

Yan, W. \& Kang, M.S. 2003. GGE-Biplot Analysis: A Graphical Tool for Breeders, Geneticists, and Agronomists. Boca Raton: CRC Press.

Yan, W. \& Rajcan, I. 2002. Biplot analysis of test sites and trait relations of soybean in Ontario. Crop Science 42(1): 11-20.
Adeel Riaz*

Department of Plant Breeding and Genetics

University of Agriculture Faisalabad

Pakistan

Adeel Riaz* \& Sadaruddin Chachar

Biotechnology Research Institute

Chinese Academy of Agricultural Sciences

Beijing, 100081

China

Muhammad Shahid Iqbal

Cotton Research Institute

Chinese Academy of Agricultural Sciences

Anyang

China

\section{Sajid Fiaz}

State Key Laboratory of Rice Biology

China National Rice Research Institute

Hangzhou, 310006

China

Rai Muhammad Amir

Institute of Food and Nutritional Sciences

PMAS-ARID Agriculture University

Rawalpindi, Pakistan

Bisma Riaz

Institute of Crop Sciences

Chinese Academy of Agricultural Sciences

Beijing, 100081

China

*Corresponding author; email: adeelriaz1991@yahoo.com

Received: 26 November 2018

Accepted: 11 November 2019 